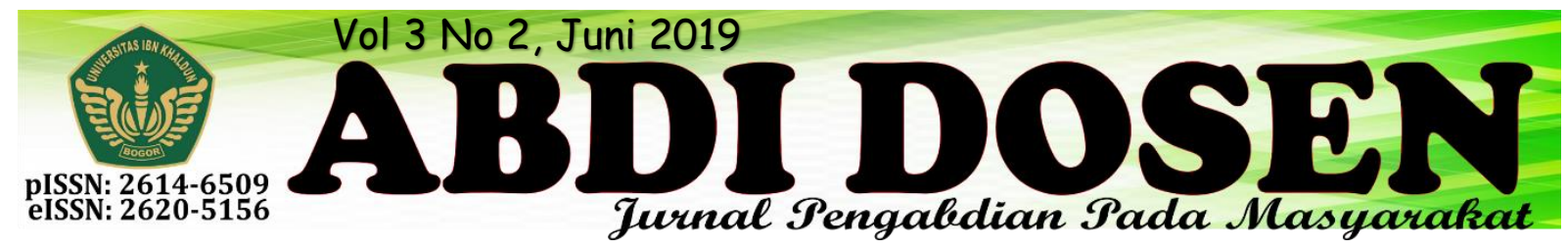

\title{
CERDAS BERSAMA MEMBANGUN MASYARAKAT YANG PEDULI PERMASALAHAN PENDIDIKAN DAN LINGKUNGAN
}

\author{
Rusdi Kasman ${ }^{1}$, Hafidzul Mubin, Ananya Larasati, Cahya Gilang Widhi Prakarsa ${ }^{2}$ \\ rusdikasman@uika-bogor.ac.id \\ Fakultas Keguruan dan Ilmu Pendidikan Universitas Ibn Khaldun'르, Mahasiswa KKN Kelompok 50 Tahun $2018^{2}$
}

\begin{abstract}
ABSTRAK
Kegiatan KKN Terintegrasi Universitas Ibn Khaldun Bogor tahun 2018 merupakan salah satu kegiatan dengan pendekatan community development, dimana pada pelaksanaan kegiatan ini melakukan proses perencanaan sekaligus aksi program Pendampingan masyarakat baik pada aspek sosial, ekonomi, kesehatan, pendidikan, hukum, dan agama maupun teknologi tepat guna secara terpadu. Tujuan daripada KKN ini adalah untuk membantu masyarakat memudahkan dalam menjalani aktifitas serta mendapatkan ilmu pengetahuan yang berkesinambungan di kehidupan sehari-hari. Metode yang digunakan adalah metode kualitatif yang mengambarkan pengaplikasian program pendidikan dan pemberdayaan lingkungan yang ada dengan mengaplikasian pembuatan kompos dan lubang biopori.
\end{abstract}

Kata Kunci : Lingkungan, Pendidikan, KKN.

\section{PENDAHULUAN}

Analisis Situasi

Kuliah Kerja Nyata adalah bagian dari sistem Pendidikan Tinggi yang menempatkan mahasiswa di luar kampus agar mahasiswa hidup ditengah-tengah masyarakat bersama masyarakat untuk membantu dan mendampingi masyarakat memanfaatkan potensi sumber daya alam lokal dan sumber daya manusia yang ada untuk mengatasi permasalah masyarakat dalam kurun waktu tertentu. KKN Tematik Terintegrasi Universitas Ibn Khaldun Bogor merupakan salah sebuah tuntutan / kewajiban bagi mahasiswa semester VI. Sasaran KKN bagi masyarakat yakni untuk meningkatkan kesadaran masyarakat dengan berperan aktif dalam mengembangkan produktifitas sumber daya pembangunan sesuai dengan fasilitas yang dimiliki.
Kegiatan KKN Terintegrasi Universitas Ibn Khaldun Bogor tahun 2018 merupakan salah satu kegiatan dengan pendekatan community development, di mana pada pelaksanaan kegiatan ini melakukan proses perencanaan sekaligus aksi program Pendampingan masyarakat baik pada aspek sosial, ekonomi, kesehatan, pendidikan, hukum, dan agama maupun teknologi tepat guna secara terpadu.

Desa Purwabakti merupakan salah satu tempat yang di pilih dan ditunjuk LPPM untuk menjadi tempat pelaksanaan kuliah kerja nyata yang bertemakan Tematik Terintegrasi. Anggota posko berjumlah 14 orang yang berasal dari fakultas dan jurusan yang berbeda-beda.

Berdasarkan hasil survey yang dilakukan di Desa Purwabakti tanggal 2-3 
Agustus 2018, dipilihlah satu kampung yaitu Kampung Cipamubutan dengan RW sasaran RW 04 yang berjumlah 4 RT. Desa Purwabakti dan kampung Cipamubutan mempunyai masyarakat yang heterogen atau beragam serta memiliki keragaman permasalahan pada aspek pendidikan ekonomi, kesehatan, pendidikan, hukum, dan agama maupun teknologi, sehingga dalam penyusunan serta perencanaan suatu program disesuaikan dengan kondisi, situasi dan potensi yang dimiliki oleh lokasi setempat. Setelah melihat hasil survey dan menganalisis daerah maka Tim KKN Posko 50 di tempatkan di Desa Purwabakti tepatnya dikampung Cipamubutan RW 04 memilih untuk menyusun program yang mencakup enam pilar utama yaitu, Agama, Hukum, Kesehatan, Ekonomi, Pendidikan dan Teknik.

Adapun program yang direncanakan meliputi : 1) pilar pendidikan adalah mengadakan pembelajaran pada Pendidikan Anak Usia Dini (PAUD) dan masyarakat Sekitar, mengadakan Bimbel (Bahasa Inggris, Membantu mengerjakan pr, dan Komputer), Pengadaan Keaksaraan Usaha Mandiri. 2) Pilar Teknik adalah memperhatikan masalah sampah (lubang biopori dan kompos), membuat plang pembatas. 3) Pilar Ekonomi, program yang telah disiapkan adalah Menabung sejak dini, melakukan pelatihan kreatifitas memasak dengan memanfaatkan SDM di sekitar. 4) Pilar Kesehatan adalah melakukan Penyuluhan PHBS dan Senam Sehat. 6) Pilar Agama yang telah disiapkan adalah peningkatan nilai-nilai spiritual dan religiusitas melalui kegiatan pengajian anak-anak dan pengajian ibu-ibu. 7) Program Pilar Hukum yang telah disiapkan adalah penyuluhan tentang $\mathrm{LBH}$.

\section{Keadaan Geografis}

Desa Purwabakti merupakan salah satu Desa diwilayah Kecamatan Pamijahan Kabupaten Bogor dengan Luas 1.662 Ha, diatas permukaan laut 520-1350 M, dan mempunyai unsur pembantu Pemerintah terbawah, terdiri dari 5 Dusun, 12 Rukun Warga (RW), dan 41 Rukun Tetangga (RT). Batas wilayah Desa Purwabakti sebagai berikut :

$\begin{array}{ll}\text { Sebelah Utara } & \text { : Desa Ciasmara } \\ \text { Sebelah Timur } & \text { : Desa Ciasmara } \\ \text { Sebelah Selatan } & \text { : Desa Kabupaten } \\ & \text { Sukabumi } \\ \text { Sebelah Barat } & \text { : Desa Cibunian }\end{array}$

\section{Kondisi Demografi}

Jumlah penduduk Desa Purwabakti sampai dengan bulan Juli 2018 adalah sebanyak 7.219 Jiwa terdiri dari

$\begin{array}{lr}\text { Laki-laki } & : 3.793 \text { Jiwa } \\ \text { Perempuan } & : 3.417 \text { Jiwa } \\ \text { Jumlah KK } & : 1.961 \mathrm{KK} \\ \text { Jumlah Keluarga Miskin: } 600 \mathrm{KK}\end{array}$

\section{Kondisi Sosial}

Mengenai keadaan penduduk berdasarkan Agama adalah sebagai berikut:

$\begin{array}{ll}\text { Islam } & : 7.219 \text { Orang } \\ \text { Kristen } & :- \\ \text { Protestan } & :- \\ \text { Hindu } & :- \\ \text { Budha } & :- \\ \text { Konghucu } & :-\end{array}$

Keadaaan Mata Pencaharian penduduk Desa Purwabakti adalah sebagai berikut :

$\begin{array}{ll}\text { Petani } & : 781 \text { Orang } \\ \text { Buruh Tani } & : 538 \text { Orang } \\ \text { Pedangang } & : 747 \text { Orang } \\ \text { PNS } & : 4 \text { Orang } \\ \text { TNI/Polri } & :- \\ \text { Karyawan Swasta } & : 215 \text { Orang } \\ \text { Wiraswasta } & : 217 \text { Orang } \\ \text { Karyawan BUMN } & :-\end{array}$


Latar belakang Pendididkan

penduduk Desa Purwabakri adalah sebagai berikut:

Tidak tamat SD : :334 Orang

Tamat SD : : 1.609 Orang

Tamaat SLTP $\quad: 1.035$ Orang

Tamat SLTA : 542 Orang

Tamat Akademi :-

S1

: 15 Orang

S2

\section{Sarana dan Prasarana}

a. Sarana dan prasarana pemerintahan

Desa Purwabakti adalah sebagai berikut:

1. Kantor Desa $\quad: 1$ Buah

2. Balai Pertemuan/Aula : 1 Buah

3. Poskamdes :1 Buah

4. Mushola Desa : - Buah

5. Kendaraan Dinas Roda Dua : 3 Buah

6. Kendaraan Dinas Rod Empat : 1 Buah
7. Meja Kerja
: 5 Buah
8. Kursi Kerja
: 5 Buah
9. Komputer
: 3 Unit
10. Mesin TIK
: 2 Unit

b. Sarana dan Prasaran Perhubungan

Desa Purwabakti adalah sebagai berikut:
1. Jalan Beton
: $100 \mathrm{KM}$
2. Jalan Hotnik
: $600 \mathrm{KM}$
3. Jalan Aspal
$:-$
4. Jalan Pengerasan
: $200 \mathrm{KM}$
5. Jalan Tanah
: $4500 \mathrm{KM}$
6. Jalan Gang
: $1200 \mathrm{KM}$
7. Jembatan
: 21 Buah

c. Sarana dan prasarana pendidikan umum Desa Purwabakti adalah sebagai berikut:
1. TK
: 2 Buah
2. PAUD
: 2 Buah
3. SD
: 3 Buah
4. SLTP
$:-$
5. SMU/SMK
$:-$
6. Perguruan tinggi

7. Tempat kursus : -

d. Sarana dan prasarana pendidikan islam Desa Purwabakti adalah sebagai berikut:

1. RA/TT Al-Qur'an : 2 Buah

2. Madrasah Ibtidaiyah : 1 Buah

3. Madrasah Tsanawiyah: -

4. Madrasah Aliyah : -

5. Pondok Pesantren : 13 Buah

6. Majlis Ta'alim $\quad: 11$ Buah

e. Sarana dan prasarana peribadatan

Desa Purwabakti adalah sebagai berikut:

$\begin{array}{ll}\text { 1. Masjid } & : 19 \text { Buah } \\ \text { 2. Musollah } & : 52 \text { Buah } \\ \text { 3. Gereja } & :- \\ \text { 4. Vihara } & :- \\ \text { 5. Pure } & :-\end{array}$

f. Sarana dan prasarana kesehatan Desa

Purwabakti adalah sebagai berikut :

1. Puskesmas

2. BKIA/Rumah Bersalin : -

3. Poliklinik :-

4. Posyandu : 11 Buah

5. Apotek :1 Buah

g. Sedangkan jumlah tenaga medis yang ada dan melaksanakan prakter di desa Purwabakti adalah sebagai berikut :

1. Dokter pukesmas : -

2. Dokter praktek swasta :-

3. Bidan desa $\quad: 1$ Orang

4. Bidan praktek swasta :-

5. Dukun beranak terlatih: 2 Orang

6. Dukun beranak tidak terlatih: 7 Orang

7. Kader posyandu : 55 Orang

h. Fasilitas perekonomi / perdagangan desa Purwabakti adalah sebagai berikut:

1. Bank pemerintahan :-

2. Pasardesa : 1 unit

3. Kios/ruko : 135 unit

4. Material : 1 unit

5. Wartel :-

6. Warnet : 1 unit 
7. Tukang Bensin Eceran : 28 unit

8. Depot isi ulang air minum: -

9. Peternak Ayam : 2 unit

10. Penggilingan Padi : 12 unit

i. Lain-lain fasilitas sarana olahraga Desa Purwabakti adalah sebagai berikut:

1. Lapangan bola :2 unit

2. Lapangan badminton : 1 unit

3. Lapangan basket :-

4. Lapangan bola voly :-

5. Tenis meja

6. Lapangan tenis :-

\section{Kondisi Masyarakat}

Secara umum kondisi politik serta ketentraman dan ketertiban wilayah di Desa Purwabakti cukup aman dan terkendali, dalam hal ini kehidupan politik masyarakat dapat tersalurkan sesuai dengana aspirasinya, seiring dengan bergulirnya reformasi dan banyak partai politik yang berkembang pada saat ini.

Berkaitan dengan masalah keamanan dan keteriban dapat disampaikan bahwa pada kurun waktu 1 (Satu) tahun situasi dan kondisi Desa Purwabakti terbilang aman.

Adapun gangguan keamanan dan ketertiban dalam kurun waktu 1 (Satu) tahun antara lain:

1. Pencurian sebanyak :- Kejadian

2. Pembunuhan sebanyak :- Kejadian

3. Penganiayaan sebanyak :-Kejadian

4. Penipuan sebanyak : - Kejadian

5. Penemuan Mayat Sebanyak: - Kejadian

6. Bencana Alam Sebanyak : 21 Kejadian

7. Kecelakaan Sebanyak : - Kejadian

8. Pemerkosaan :- Kejadian Adapun jumlah anggota

Perlindungan Masyarakat (LINMAS) sampai pada saat ini tercatat sebanyak 20 ( Dua Puluh ) orang berkaitan dengan kelembagaan Linmas, dimana saat ini sudah ada di Pemerintahan Kabupaten Bogor dengan adanya kantor Kesbangpol dan Linmas yang mengatur tentang keberadaan Linmas ditingkat Kabupaten Bogor, sesuai dengan berubahnya organisasi dan tata kerja Pemerintahan Kabupaten Bogor. 


\section{METODE PELAKSANAAN}

\section{Tahapan Pelaksanaan}

Tahapan pelaksanaan untuk kegiatan ini sebagaimana terlihat pada bagan sebagai berikut:

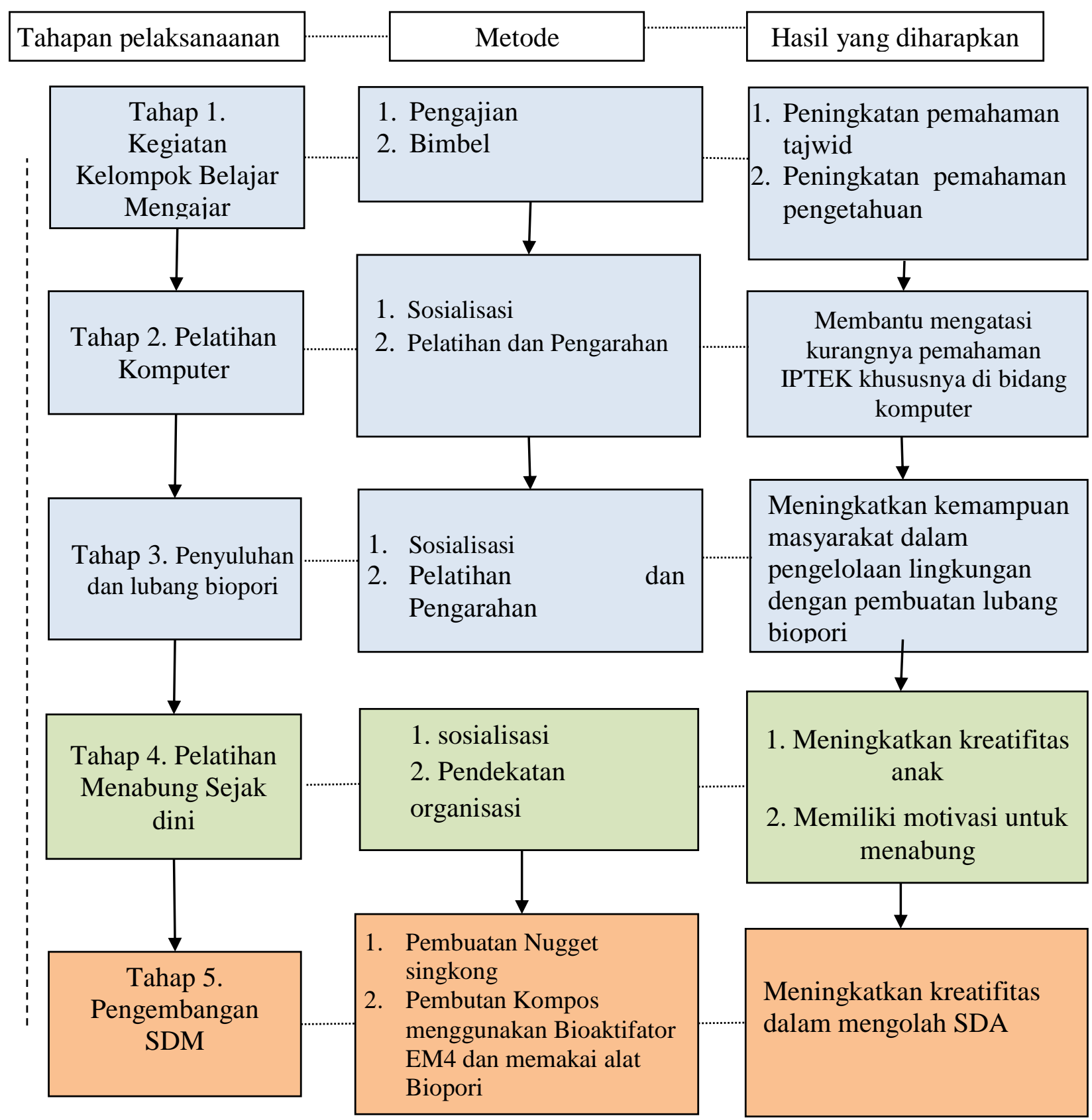




\section{Metode Pendekatan}

Pendekatan community developmen

Pendekatan yang digunakan dalam

kegiatan ini adalah:

1. Pendekatan Religius

Yaitu pendekatan yang menggunakan nilai-nilai agama sebagai basis kegiatan.

2. Pendekatan Organisasi

Organisasi merupakan hal yang memiliki peran penting di tengahtengah masyarakat. Pendekatan organisasi di lakukan untuk mempermudah pengenalan kami kepada warga Desa Purwabakti kp. cipamubutan. Karena suatu himpunan dapat menjadi tolak ukur penilaian terhadap anggota yang tergabung di dalamnya.

3. Pendekatan Sosial

Pendekatan ini dilakukan agar mudah berinteraksi, berdiskusi dan berbaur dengan masyarakat setempat. Serta agar program yang dijalankan dapat dibantu serta bekerjasama sesuai dengan kemampuan masing-masing.

4. Pendekatan Edukasi

Desa Purwabakti kp. cipamubutan memiliki masyarakat yang memiliki latar belakang yang berbeda-beda. Tidak semua masyarakat mempunyai pengetahuan yang lebih modern dalam menjalankan kehidupan sehari-hari di lingkungannya. Maka dari itu pendekatan edukasi sangatlah di perlukan untuk mempermudah pendekatan dan pengenalan program kami kepada warga.I

5. Pendekatan Partisipatori

Pendekatan ini berorientasi pada upaya peningkatan peran langsung dari peserta KKN dalam proses dan pelaksanaan kegiatan.

\section{Partisipasi Masyarakat dalam pelaksanaan program}

Partisipasi masyarakat yang dilakukan dalam kegiatan adalah: 1. Mendukung program yang diadakan kelompok kkn 50

2. Memberikan bantuan moril

3. Ikut berpartisipasi pada setiap kegiatan yang di rencanakan

4. Antusias dalam kegiatan yang diselenggarakan

5. Memberikan saran dan masukan terhadap keberlangsungan program.

\section{Langkah Evaluasi}

Evaluasi yang akan dilakukan terdiri dari:

1. Evaluasi proses, yakni evaluasi yang terkait dengan perencanaan serta pelaksanaan kegiatan. Evaluasi proses akan dilakukan setiap pekan oleh seluruh anggota kelompok 50.

2. Evaluasi hasil, yakni evaluasi yang akan dilaksanakan setelah kegiatan berlangsung. Evaluasi hasil ditujukan untuk menguji pemahaman warga, sudah sejauh mana mereka mengerti serta paham dengan pembinaan dan seminar yang sudah pernah disosialisasikan oleh mahasiswa KKN kelompok 50 Universitas Ibn Khaldun Bogor. 


\section{HASIL DAN PEMBAHASAN}

\section{Pelaksanaan Program}

Bidang Pendidikan

Ada berapa program yang kami lakukan pada bidang pendidikan diantaranya :

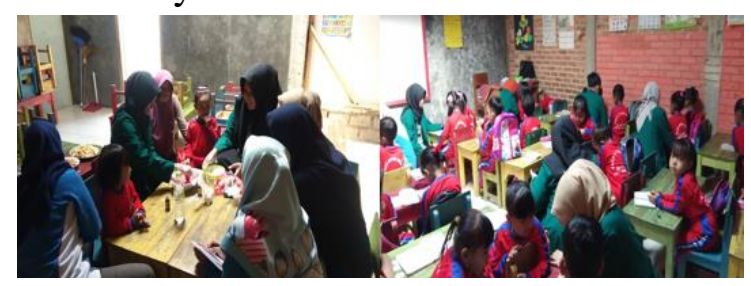

a. Pengembangan PAUD

Pendidikan anak usia dini (PAUD) adalah jenjang pendidikan sebelum jenjang pendidikan dasar yang merupakan suatu upaya pembinaan yang ditujukan bagi anaksejak lahir sampai dengan usia enam tahun yang dilakukan melalui pemberian rangsangan pendidikan untuk membantu pertumbuhan dan perkembangan jasmani dan rohani agar anak memiliki kesiapan dalam memasuki pendidikan lebih lanjut, yang diselenggarakan pada jalur formal, nonformal, dan informal.

Pendidikan anak usia dini merupakan salah satu bentuk penyelenggaraan pendidikan yang menitikberatkan pada peletakan dasar ke arah pertumbuhan dan 6 (enam) perkembangan: agama dan moral, fisik motorik, kognitif, bahasa, sosial-emosional, dan seni, sesuai dengan keunikan dan tahap-tahap perkembangan sesuai kelompok usia yang dilalui oleh anak usia dini seperti yang tercantum dalam Permendikbud 137 tahun 2014 tentang Standar Nasional PAUD (menggantikan Permendiknas 58 tahun 2009).

Ada dua tujuan diselenggarakannya pendidikan anak usia dini, yaitu: Tujuan utama: untuk membentuk anak Indonesia yang berkualitas, yaitu anak yang tumbuh dan berkembang sesuai dengan tingkat perkembangannya sehingga memiliki kesiapan yang optimal di dalam memasuki pendidikan dasar serta mengarungi kehidupan pada masa dewasa.Tujuan penyerta: untuk membantu menyiapkan anak mencapai kesiapan belajar (akademik) di sekolah, sehingga dapat mengurangi usia putus sekolah dan mampu bersaing secara sehat di jenjang pendidikan berikutnya.

Rentangan anak usia dini menurut Pasal 28 UU Sisdiknas No.20/2003 ayat 1 adalah 0-6 tahun. Sementara menurut kajian rumpun keilmuan PAUD dan penyelenggaraannya di beberapa negara, PAUD dilaksanakan sejak usia 0-8 tahun (masa emas).

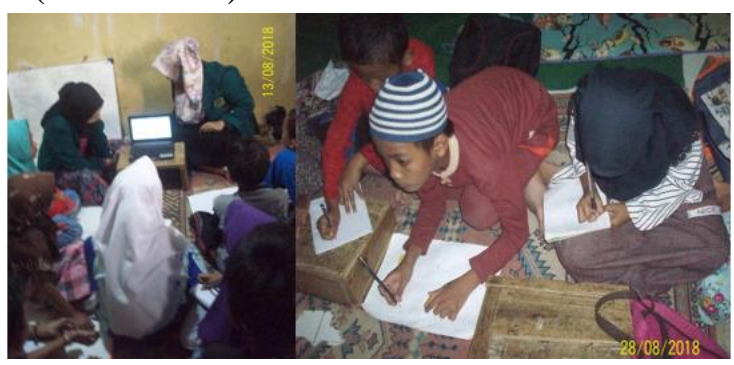

b. Pelatihan Bahasa Inggris (Bimbel)

Secara harfiah, istilah bimbingan berasal dari bahasa Inggris yaitu "guidence". Guidence dapat diartikan sebagai bimbingan, bantuan, pimpinan, arahan, pedoman, petunjuk. Guidence sendiri berasal dari kata "(to) guide" yang berarti menuntun, mempedomi, menjadi petunjuk jalan, mengemudikan. Adapun pembahasan dalam buku ini kata guidance dipergunakan untuk pengertian bimbingan atau bantuan.

Secara umum bimbingan dapat diartikan sebagai suatu proses pemberian bantuan kepada individu atau kelompok yang dilakukan secara berkesinambungan supaya individu atau kelompok tersebut dapat memahami dirinya sendiri, sehingga dia sanggup mengarahkan 
dirinya dan dapat bertindak secara wajar, sesuai dengan tuntutan dan keadaan lingkungan sekolah, keluarga, masyarakat dan kehidupannya.

Materi yang diberikan mulai vocabulari dan berakhir pada coversation.

\section{c. Pelatihan bimbel Matematika (Bimbel)}

Materi yang diberikan mulai dari pertambahan, pengurangan, pembagian, perkalian, fpb dan kpk dan berakhir pada perhitungan aljabar.

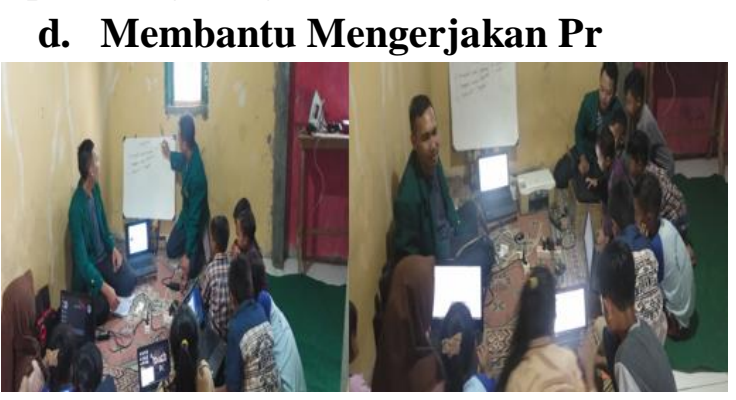

\section{e. Pelatihan Komputer}

Kegiatan tentang bimbingan belajar komputer ini untuk edukasi anak-anak Kp. Cipamubutan RT03/RW04 tentang pentingnya mempelajari komputer. Metode yang digunakan dalam pelakasanaan program ini yaitu melalui pengumuman di poster kegiatan bimbel. Teknik yang digunakan diantaranya a)Memberikan pembelajaran komputer dengan menggunakan media laptop \& video yang menjadi penunjang bagi anakanak agar mudah dalam memahami apa yang yang disampaikan oleh pemateri, b)Memberi motivasi dengan menonton video pendek motivator, c)Memberikan kesempatan kepada siswa yang kurang mengerti dengan cara tanya jawab

\section{Bidang Keagamaan}

Ada berapa program yang kami
lakukan pada bidang pendidikan
diantaranya :

a. Pengajian Anak-anak

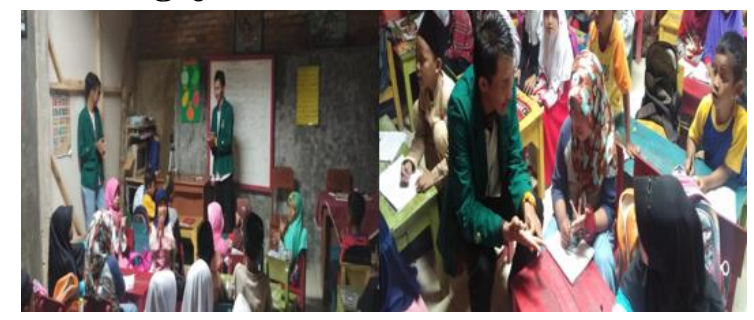

b. Mengajar di MI

Madrasah Ibtidaiyah (MI) adalah salah satu bentuk satuan pendidikan dasar yang menyelenggarakan program pendidikan enam tahun.Tujuan pendidikan di MI adalah memberikan bekal kemampuan dasar pada siswa dalam mengembangkan kehidupannya sebagai pribadi anggota masyarakat, warga Negara, serta mempersiapkan siswa untuk melanjutkan sekolah lanjutan tingkat pertama. (pasal 2 keputusan Mendikbud No. 0487 tentang Sekolah Dasar) Mengacu pada pasal 37 UU RI No. 20 Tahun 2003 tentang sistem pendidikan Nasional .

Istilah madrasah telah dikenal oleh masyarakat muslim sejak masa kejayaan Islam klasik. Dilihat dari segi bahasa, madrasah merupakan isim makãn (nama tempat) berasal dari kata darasa yang berarti tempat orang belajar (Munawir, 1997: 397). Dengan demikian madrasah dipahami sebagai tempat atau lembaga pendidikan Islam.

Dalam kamus besar bahasa Indonesia madrasah adalah sekolah atau perguruan yang biasanya berdasarkan agama Islam (Departemen Pendidikan dan Kebudayaan, 1994: 611). Madrasah di Indonesia merupakan istilah bagi sekolah agama Islam terutama sekolah dasar dan menengah, sedangkan di negara-negara Timur Tengah madrasah merupakan sekolah secara umum atau lembaga pendidikan pada umumnya 
terutama

pendidikan

tinggi

(Poerbakawatja, 1982: 199).

\section{Bidang Kesehatan}

Program bidang kesehatan yang telah kami siapkan adalah :

\section{a. Mengoptimalisasi Kinerja Posyandu}

Posyandu merupakan salah satu bentuk Upaya Kesehatan Bersumber Daya Masyarakat (UKBM) yang dikelola dan diselenggarakan dari, oleh, untuk dan bersama masyarakat dalam penyelenggaraan pembangunan kesehatan, guna memberdayakan masyarakat dan memberikan kemudahan kepada masyarakat dalam memperoleh pelayanan kesehatan dasar, utamanya untuk mempercepat penurunan angka kematian ibu dan bayi.

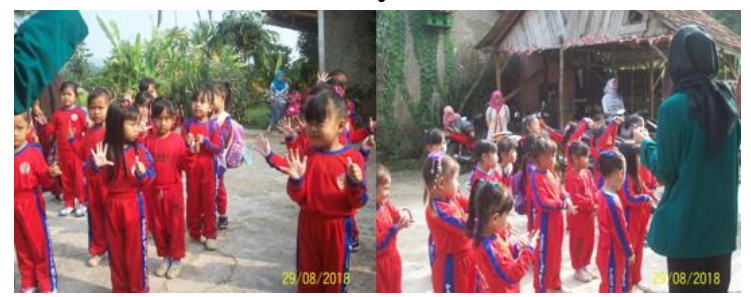

\section{b. Penyuluhan kesehatan (PHBS)}

Perilaku hidup bersih dan sehat merupakan seperangkat Prilaku manusia yang dibangun dan dikembangkan dalam kehidupan sehari - hari. Semua prilaku kesehatan Yang dilakukan atas kesadaran sehingga anggota keluarga atau keluarga dapat menolong dirinya sendiri dibidang kesehatan dan berperan aktif dalam kegiatan - kegiatan di masyarakat (Depkes, 2007).

Masa anak usia dini merupakan peletakan dasar perkembangan perilaku anak terutama prilaku kesehatan (margawati, sri 2012).

Kami melaksanakan Penyuluhan kesehatan tentang Perilaku Hidup Bersih dan Sehat (PHBS) tentang bagaimana cara mencuci tangan yang baik dan benar, yang dilakukan pada hari Rabu 29 Agustus 2018 dimulai pukul 08.00 -
09.00 bertempat di PAUD Citra Mulia RT 03/04 Desa Purwabakti Kampung cipamubutan. pemateri atau promotor kesehatan dari kita sendiri dan menggunakan media visual. Memaparkan enam langkah cara mencuci tangan yang baik dan benar, serta menjelaskan bahaya dan manfaat cuci tangan.

Menurut Green perilaku Kesehatan dipengaruhi oleh 4 faktor dalam perilaku yaitu: 1). Predisposing Factors meliputi: Pengetahuan, sikap, tradisi, kepercayaan, nilai, pendidikan, sosial ekonomi, 2). Enabling Factors meliputi: Fasilitas yang mempengaruhi kesehatan, dan Pelayanan ksehatan yang dapat dijangkau, serta 3). Reinforcing Factors, meliputi: Sikap dan kebijakan serta kebijakan Tokoh masyarakat, undang-undang, dan tenaga kesehatan. Menurut John B Walton dalam Notoatmojo (2010) perilaku merupakan proses belajar asosiatif dan proses belajar stimulus-respons.Upaya intervensi pembentukan perilaku melalui tekanan (enforcement) seperti peraturan, tekanan dan sanksi dan edukasi (education) melalui persuasi, himbauan, ajakan, membangun kesadaran. (margawati, sri 2012).

\section{c. Senam Jantung}

Pada dasarnya olahraga ini berintikan olahraga aerobik yakni olahraga yang banyak menghirup oksigen. Program Senam jantung sehat menarik dan meriah untuk meningkatkan terbinanya kebersamaan yang akrab dalam suasana kekeluargaan. Olahraga ini murah dan massal agar terjangkau oleh siapa pun dan cepat berkembang. Selain itu, olahraga ini aman karena adanya pelatih dan dokter sebagai syarat berdiriny klub jantung sehat (Suparto, 2003:141). 
Senam Jantung Sehat ini juga dapat melenturkan otot dan sendi. Selain itu, dapat menghilangkan kekakuan otot serta menambah kekuatan otot tangan dan kaki. Dengan demikian maka olahraga jantung sehat adalah olahraga yang berintikan aerobik ditambah dengan olahraga yang dapat memberikan kelentukan, kekuatan dan peningkatan otot-otot secara mudah, murah, meriah, massal, manfaat serta aman. Sewaktu latihan harus melakukan pengukuran denyut nadi, atau denyut jantung, nadi sebelum latihan, nadi sesudah pemanasan, nadi setelah program inti, dan nadi sesudah pendinginan. Pengamanan yang sederhana hanya mengitung deyut nadi tetapi gunanya sangat bermanfaat. Dosis yang diberikan sesuai dengan umur.

\section{Bidang Lingkungan}

Program bidang lingkungan yang telah kami siapkan adalah :

\section{a. Kerja Bakti}

Kerja bakti yang kami rencanakan termasuk kedalam salah satu program posdaya jangka panjang yang telah kami bentuk. Dengan rencana awal, kerja bakti dilakukan setiap hari Jumat pagi di wilayah RT 03 dan RT 04 yang dimulai dari sarana ibadah serta lingkungan sekitar.

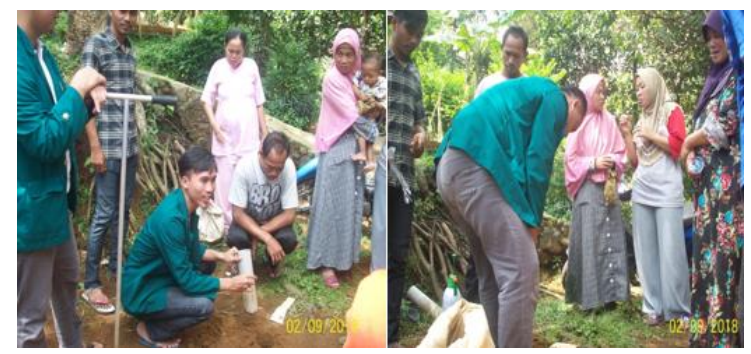

\section{b. Pengadaan Lubang Biopori}

2 september pagi di halaman RT 03 dengan mengajak para warga untuk ikut andil dalam pembuatan lubang biopori.

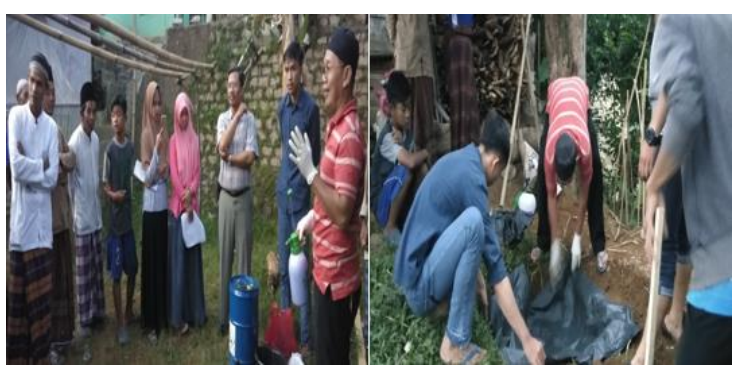

\section{c. Pembuatan kompos}

pembuatan kompos dilaksanakan dilingkungan sekitar dengan satu pemateri yang berasal dari IPB. Dalam pembuatan kompos di Desa Purwabakti kp. Cipamubutan kami menggunakan bahan utama yakni EM4.

\section{Bidang Ekonomi}

Program bidang ekonomi yang telah kami siapkan adalah :

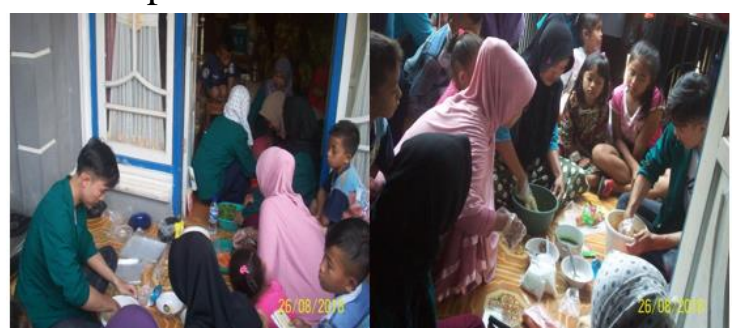

a. Pelatihan Sumber Daya Manusia

Di dalam melaksanakan pelatihan sumber daya manusia kami mengajak ibu-ibu PPK membuat nugget yang bahan dasar utamanya ialah singkong, yang dimana singkong merupakan hasil pertanian di Desa Purwabakti di kp. Cipamubutan. Pemateri atau promotor dari kita sendiri. Dengan harapan para ibu-ibu PKK dapat mengembangkan kreatifitas memasak dan memanfaatkan sela waktkunya untuk berwirausaha seperti membuat kerajinan,makanan dll.

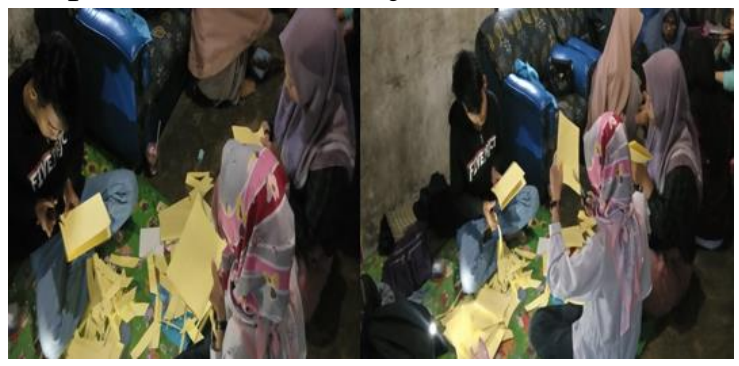

b. Program Menabung Sejak Dini 
Menurut KBBI, menabung adalah menyimpan uang (di celengan, pos, bank, dan sebagainya). Sikap gemar menabung perlu ditanamkan pada anak sejak usia dini untuk menghindari perilaku gemar foya-foya.

Menabung berarti menyisihkan sebagai uang yang dimilki untuk disimpan dalam jangka waktu tertentu. Menabung merupakan kegiatan yang tidak boleh dilupakan, kegiatan ini penting. Menabung harus dibiasakan sejak dini. Menabung merupakan kegiatan yang positif. Dengan menabung kita bisa menjadi pribadi yang lebij hemat dan tentu juga kita dapat mengatur keungan (Syatriadi, 2013). Tujuan menabung membiasakan diri hidup hemat - Hidup hemat berarti tidak boros. Pengeluaran disesuaikandengan kebutuhan dan memenuhi kebutuhan dalam jumlah besar dikeudian hari (Maulana,2015). Selain itu, mengajarkan menabung sejak usia dini memiliki manfaat yaitu anak terbiasa belajar mengelola uang pribadi, memiliki perencanaan keuangan, menghargai uang, belajar disiplin, dan membuat kebanggan (Olvista, 2013).

\section{Bidang Hukum}

Program bidang hukum yang telah kami siapkan adalah :

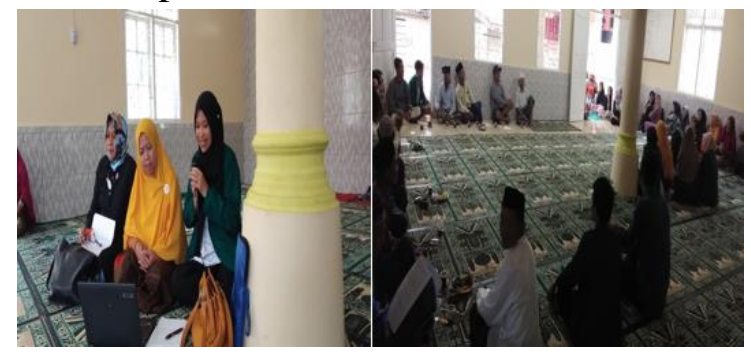

\section{a. Penyuluhan mengenai hukum pernikahan}

Sistem hukum Indonesia tidak mengenal istilah "kawin di bawah tangan" atau semacamnya, dan belum diatur dalam sebuah peraturan perundang-undangan. Namun, secara sosiologis, istilah "kawin di bawah tangan" atau "kawin sirri" diberikan bagi perkawinan yang tidak dicatat atau dilakukan tanpa memenuhi ketentuan UU Nomor 1 Tahun 1974 khususnya tentang pencatatan perkawinan yang diatur dalam Pasal 2 ayat (2) Undang-Undang Nomor 1 Tahun 1974.

Nikah di bawah tangan adalah sah jika dilaksanakan sesuai dengan syariat Islam, sepanjang tidak ada motif "Sirri"(dirahasiakan nikahnya dari orang banyak). Nikah semacam ini bertentangan dengan ajaran Islam dan bisa mengundang fitnah, serta dapat mendatangkan madarat atau reseko berat bagi pelakuknya, khususnya pihak wanita dan keluargaanya. Hal ini sesuai dengan pendapat Abdul Mujib, Wakil Ketua Pengadilan Agama Tanah Grogot Kaltim,2010). Hal ini didasarkan pada Hadist Nabi yang diriwayatkan oleh Menurut suatu riwayat, Khalifah Umar bin al-Khattab pernah mengancam pelaku nikah sirri dengan hukuman had (dera atau rajam), jika telah terjadi hubungan seksual antara keduanya dan diakuinya atau dengan kesaksian empat orang saksi.

Kata "sirri" dari segi etimologis berasal dari bahasa arab, yang arti harfiyahnya "rahasia" (secret). Dengan demikian Nikah Sirri dapat diartikan adalah "Nikah yang atas pesan suami, para saksi merahasiakannya untuk isterinya atau jama'ahnya, sekalipun keluarga setempat".

\section{Program Tambahan}

a. Memperingati HUT RI ke - 71

Pada peringatan HUT RI - ke 72 kami bertindak sebagai panitia untuk melakukan perayaan dan dibantu oleh kawan-kawan dari STKIP 
Muhammadiyah yang kebetulan satu lingkungan dengan posko kami.

\section{b. Pembuatan pembatas RT}

Kami mengadakan program ini agar warga ataupun masyarakat yang lewat mengetahui perbatasan setiap RT Kp. Cipamubutan Desa Purwabakti.

c. Pengajian Rutin Bapak-bapak dan Ibu-ibu

Pengajian Bapak-bapak rutin dilakukan setiap dua minggu sekali, tepatnya pada malam selasa mulai dari jam $20.00-22.00$ WIB. Sedangkan pengajian ibu- ibu rutin dilakukan 3 kali dalam seminggu yaitu pada hari selasa , hari jumat dan hari minggu dimulai pukul

\section{KESIMPULAN}

Berdasarkan hasil kegiatan, pengamatan, maupun pelaksanaan program kerja KKN yang telah direncanakan, disusun dan dilaksanakan. Maka kelompok 50 KKN UNIVERSITAS IBN KHALDUN BOGOR 2018 di Desa Purwabakti Kecamatan Pamijahan mengambil beberapa kesimpulan yaitu :

1. Keberhasilan KKN tidak lepas dari kerja sama antara mahasiswa dengan perangkat desa, masyarakat serta semua pihak yang membantu dan mendukung terlaksananya kegiatan KKN tanpa adanya kerja sama yang baik, program kerja KKN tidak akan berjalan dengan lancar.

2. Dengan adanya mahasiswa KKN, para masyarakat mencoba mencontoh cara berfikir mahasiswa untuk befikir modern.

3. Dengan adanya mahasiswa $\mathrm{KKN}$ masyarakat terbantu dengan bertambahnya informasi dan ilmu pengetahuan yang mereka peroleh dari mahasiswa KKN.
07.00 - 08.00 WIB selain pengajian rutin pengajian ibu - ibu mengadakan pengajian akbar yang dilakuakan 1 bulan sekali di balai desa yang dilaksanakan pada tanggal 25 Agustus 2018 dimulai pukul $08.00-10.00$ WIB.

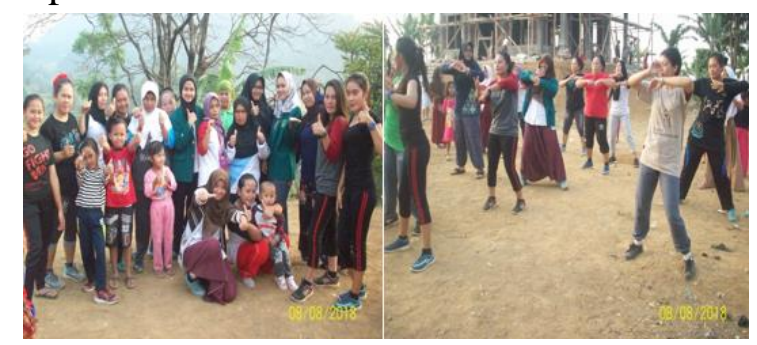

\section{d. Senam Zumba}

Senam zumba dilakukan tiga kali dalam seminggu yaitu pada hari selasa, jumat dan minggu.

4. Teori yang didapat di bangku kuliah tidak semua sesuai dengan situasi dan kondisi lapangan sehingga kami lebih banyak belajar dari masyarakat.

5. Kurangnya kepedulian masyarakat desa terhadap lingkungan sekitar.

6. Potensi desa di Desa Purwabakti telah dikelola cukup baik oleh masyarakat, sehingga tercapai hasil yang cukup memuaskan, diantaranya:

a. Kerjasama yang baik antara masyarakat, perangkat desa serta instansi terkait guna memperlancar pembangunan desa.

b. Perbaikan dan pemeliharaan jalan sehingga dapat membuka wilayah desa yang terisolisir dan dapat memperlancar transportasi.

c. Keterbukaan aparat desa terhadap masyarakat, mampu menjalin hubungan komunikasi yang baik.

d. Pemberdayaan swadaya masyarakat untuk menunjang pembangunan desa. 
Manfaat Bagi Masyarakat

Dengan tercapainya proker-proker yang telah kami laksanakan, diharapkan masyarakat bisa mendapatkan manfaat dan

\section{REFERENSI}

Administrasi Profil Desa Purwabakti

Fahmi eroby, 2008, Pendidikan berbasis masyarakat. Yogyakarta

KBBI (Kamus Besar Bahasa Indonesia) ilmu pengetahuan serta memudahkan dalam menjalani aktifitas yang berkesinambungan dalam kehidupan sehari-hari.

Jurnal Inovasi dan Kewirausahaan. PROGRAM SENTONO MENABUNG. Jamalul Lail dan Ari Maulana. Januari 2015. Vol.IV hal.54-57. 